\title{
Study on the Physicochemical Properties of Some Commercial Soaps Available in Bangladeshi Market
}

\author{
Ashrafy Habib, Sazal Kumar, Md. Sajal Sorowar, Joyanto Karmoker, \\ Mst. Khodeza Khatun, Sharif M. Al-Reza
}

Department of Applied Chemistry and Chemical Technology, Islamic University, Kushtia 7003, Bangladesh

sharif@acct.iu.ac.bd

\begin{abstract}
The quality of soaps depends on their physicochemical properties. We can determine the competency and cleaning properties of soaps by knowing the physicochemical properties. The quality of the soaps remains indistict that are sold in the local markets of Bangladesh and thus the need to assess them. Nine commercial soaps were taken for moisture content, total alkali, total fat substance, free caustic alkaly and $\mathrm{pH}$ according to documented methods of analysis. Values of moisture content ranged between $9.64 \%$ to $21.06 \%$, total alkali ranged between $0.00 \%$ to $6.20 \%$, free caustic alkali was found between $0.00 \%$ to $0.99 \%$, total fat substance was found between $68.33 \%$ to $100 \%$, pH for 5\% solution ranged between 9.69 to 10.13 and pH for $10 \%$ solution ranged between 9.63 to 10.32 .
\end{abstract}

Keywords: Soap, Moisture content, total alkali, Total fat matter, free caustic alkalinity, $p H$

\section{INTRODUCTION}

Soaps may be defined as water-soluble salt of fatty acids which contain more than eight carbon atoms [1]. The cleansing properties of soaps depend on its chemical properties as an anionic surface active agent or surfactant. Soaps are prepared by treating a strong alkaline solution with animal or vegetable fats or oils. Fats and oils are composed of triglycerides; a single molecule of glycerol attached to three molecules of fatty acids [2]. The lathering and washing properties of the soaps depend on the fatty acids such as stearic acid, myristic acid, palmitic acid, lauric acid and oleic acid which is use to prepare them [3]. At room temperature, fats are solid esters of fatty acids and glycerin while oils are the liquid glycerol esters of fatty acids. For the saponification reaction of glycerides with alkalis, $\mathrm{KOH}$ is used for liquid soaps and $\mathrm{NaOH}$ is used for solid or bar soaps [4]. The character of different soaps depends on various soap making metals such as calcium, magnesium, iron or aluminum which are not water soluble [1]. The soaps which are made by using fatty acids containing tweleve or more carbon such as coconut oil is very soluble and will lather easily even in sea water. On the otherhand, fatty acids with only 10 or fewer carbons are not used in soaps because they irritate the skin and have obnoxious odours [1]. The soap was the only cleansing substance for centuries but the price was very high due to shortage of some raw materials and only wealthy people could afford it [5]. It became available to other people only after the preparation of sodium carbonate came in handy during the manufacture of soap [5]. The first soap powder for laundry was made using sodium silicate as a builder at the end of the 19th century [5]. Though the use of sodium or potassium carbonate leads to a hard or soft soap respectively, the performance of finished soap largly depends on the chemical nature of the lipophilic part of soap [5]. The physicochemical characteristic of soap depends on several factors which include the strength and purity of alkali, the kind of oil used and completeness of saponification. Such physicochemical characteristics include moisture content, total fat matter, $\mathrm{pH}$, free caustic alkalinity etc. [6]. Sodium and potassium are commonly used in soap making, which produce water soluble soaps [1]. Good quality soap for cleansing purpose is one that strikes a balance in all the mentioned physicochemical properties. The levels of the physicochemical parameters in the Bangladeshi soaps remain indistinct and thus the quality of individual soaps also remains unknown. Herein we report the levels of physicochemical properties of selected toilet and laundry soaps that are used for cleansing purposes in Bangladeshi markets. 


\section{EXPERIMENTAL}

\subsection{Sample Collection}

In the present study, nine samples of local soaps (five toilet and four laundry soaps) were purchased from local market of Kushtia city of Bangladesh.

\subsection{Moisture Content}

$5.0 \mathrm{~g}$ of samples were taken in dried and tarred moisture dish and dried in an oven for $2 \mathrm{~h}$ at $101^{\circ} \mathrm{C}$ and this process was repeated until the weight became constant. The moisture content was determined by employing the following formula:

$\%$ Moisture content $=\left(\mathrm{C}_{\mathrm{s}}-\mathrm{C}_{\mathrm{h}} / \mathrm{C}_{\mathrm{s}}-\mathrm{C}_{\mathrm{w}}\right) \times 100$

Where

$\mathrm{C}_{\mathrm{w}}=$ weight of crucible

$\mathrm{C}_{\mathrm{s}}=$ weight of crucible + sample

$\mathrm{C}_{\mathrm{h}}=$ weight of crucible +sample after floating.

\subsection{Total Alkali}

$10 \mathrm{~g}$ of soap was added to required amount of neutralised ethanol and $1 \mathrm{~N} \mathrm{H}_{2} \mathrm{SO}_{4}$ was added. This mixture was refluxed at heating mantle untill the soap sample was dissolved in ethanol followed by hydrolysis in acidic medium. Flask was gradually cooled up to room temperature and remaining amount of sulphuric acid (after hydrolysis and neutralisation of all alkaline components in soap) was estimated by back titration with standard $1 \mathrm{~N} \mathrm{NaOH}$. The total alkali content expressed as a percentage $(\mathrm{m} / \mathrm{m})$ is given by the formula [7]:

$4.0 \times\left[\mathrm{V}_{\mathrm{a}}-\mathrm{V}_{\mathrm{b}}\right] / \mathrm{m}$ (for sodium soap)

Where, $\mathrm{V}_{\mathrm{a}}=$ Volume of Acid added in experiment, $\mathrm{V}_{\mathrm{b}}=$ Volume of Base at end point, $\mathrm{m}=$ Mass of soap used in experiment.

\subsection{Free Caustic Alkali}

To determine free caustic alkali $15 \mathrm{ml}$ of ethanol was added in $2.5 \mathrm{~g}$ of soap, 5 drops of phenolphthalein with $5 \mathrm{ml}$ of $20 \% \mathrm{BaCl}_{2}$ was added and the resulting solution was titrated against $0.05 \mathrm{M} \mathrm{H}_{2} \mathrm{SO}_{4}$, disappearance of pink color indicated the end point.

\subsection{Total Fatty Substance}

A revised method was used to obtain total fatty substance in which $10 \mathrm{~g}$ of each soap were added in $150 \mathrm{ml}$ of distilled water and heated while heating the soap solution was dissolved in $20 \mathrm{ml}$ of $15 \%$ $\mathrm{H}_{2} \mathrm{SO}_{4}$ until clear solution was formed. Fatty matter was solidified by adding $7 \mathrm{~g}$ of bee wax and reheated. Then the system was allowed to cool down to form a cake, further the cake was removed and blotted to dry. The cake was weighed to obtain total fatty matter by using the formula given below.

$\% \mathrm{TFM}=(\mathrm{A}-\mathrm{X} / \mathrm{W}) \times 100$

Where

$\mathrm{A}=$ weight of wax +oil

$\mathrm{X}=$ weight of wax samples

$\mathrm{W}=$ weight of soap

\section{6.pH}

For the $\mathrm{pH}$ determination two types of solutions were analyzed. One of the solutions was $10 \%$ and other was 5\%. The $\mathrm{pH}$ was observed by using $\mathrm{pH}$ meter (Sper 840087).

\section{RESUlts AND DisCuSSION}

For the purpose of perceiving the physical and chemical characteristics of commercially available soap prepared and sold in Bangladeshi market, the research was supervised by analyzing five toilet 
and four laundry soap samples. However, the results of physicochemical analysis reflecting the characteristics of the soap were shown in Table1.

Table1. Physicochemical properties of some commercial soap in Bangladesh

\begin{tabular}{|l|l|l|l|l|l|l|}
\hline \multicolumn{1}{|c|}{ Sample } & $\begin{array}{c}\text { Moisture } \\
\text { content }(\%)\end{array}$ & $\begin{array}{c}\text { Total alkali } \\
(\%)\end{array}$ & $\begin{array}{c}\text { Fee caustic } \\
\text { alkali }(\%)\end{array}$ & $\begin{array}{c}\text { Total fatty } \\
\text { matter }(\%)\end{array}$ & $\begin{array}{c}\text { pH of 5\% } \\
\text { amount of soap }\end{array}$ & $\begin{array}{c}\text { pH of } 10 \% \\
\text { amount of soap }\end{array}$ \\
\hline Toilet soaps \\
\hline Lux & $11.30 \pm 0.02$ & $1.24 \pm 0.04$ & $0.62 \pm 0.02$ & $85.10 \pm 0.01$ & $9.73 \pm 0.04$ & $9.73 \pm 0.03$ \\
\hline Meril & $9.64 \pm 0.03$ & $1.45 \pm 0.01$ & $0.08 \pm 0.01$ & $73.37 \pm 0.02$ & $9.79 \pm 0.02$ & $9.81 \pm 0.02$ \\
\hline Lifebouy & $11.80 \pm 0.05$ & $0.99 \pm 0.00$ & $0.06 \pm 0.00$ & $87.23 \pm 0.04$ & $9.71 \pm 0.01$ & $9.63 \pm 0.01$ \\
\hline Dettol & $10.97 \pm 0.01$ & $0.00 \pm 0.01$ & $0.00 \pm 0.03$ & $100.0 \pm 0.00$ & $9.79 \pm 0.01$ & $9.68 \pm 0.01$ \\
\hline Harmony & $9.88 \pm 0.00$ & $1.24 \pm 0.01$ & $0.09 \pm 0.02$ & $87.75 \pm 0.02$ & $9.69 \pm 0.02$ & $9.75 \pm 0.02$ \\
\hline Laundry soaps \\
\hline Chaka ball & $21.06 \pm 0.04$ & $6.20 \pm 0.02$ & $0.99 \pm 0.03$ & $68.33 \pm 0.07$ & $9.92 \pm 0.06$ & $10.05 \pm 0.03$ \\
\hline Tibet 570 & $14.75 \pm 0.01$ & $1.18 \pm 0.00$ & $0.14 \pm 0.02$ & $72.07 \pm 0.02$ & $10.06 \pm 0.01$ & $10.17 \pm 0.01$ \\
\hline Wheel & $17.08 \pm 0.07$ & $1.89 \pm 0.03$ & $0.18 \pm 0.01$ & $79.37 \pm 0.01$ & $10.13 \pm 0.00$ & $10.31 \pm 0.02$ \\
\hline Tibet ball & $15.14 \pm 0.02$ & $2.48 \pm 0.03$ & $0.68 \pm 0.01$ & $71.40 \pm 0.05$ & $10.11 \pm 0.02$ & $10.32 \pm 0.02$ \\
\hline
\end{tabular}

\subsection{Moisture Content}

Moisture attributes the existence of liquid especially water, usually in trace extent. The percentage of moisture contents of toilet soap samples were observed from $9.64 \%$ to $11.80 \%$. While the percentage of moisture content in the laundy soap samples were $14.75 \%$ to $21.06 \%$. Chaka ball had high moisture content as compared to other samples. From our experiment Dettol, Lux, Lifebouy and Tibet 570 fall within the limits of Encyclopedia of Industrial Chemical Analysis (10\% - 15\%). This difference in results may be due to the soap preparing methods.

\subsection{Total Alkali}

Total alkalinity means the presence of total alkaline components (hydroxides, sodium (II) oxide, carbonates and bicarbonates) in the finished soap. The common alkal is utilized in soap manufacturing are potassium hydroxide $(\mathrm{KOH})$ and sodium hydroxide $(\mathrm{NaOH})$ also known as caustic soda [8]. It involves the putrefaction of soap by known volume of standard volumetric mineral acid solution, removal of the liberated fatty matter by heating [9]. The obtained results for total alkali content of toilet soap samples were observed from $0.00 \%$ to $1.45 \%$, while the results found for laundy soaps were in between $1.18 \%$ to $6.20 \%$. The results showed that toilet soaps showed lesser $\%$ of total alkali as compared to the laundry samples. The alkalinity favors detergency [10].

\subsection{Free Caustic Alkali}

Free caustic alkali specifies the abrasiveness of any soap [11]. The free caustic alkali is the amount of alkali free to counter and avert the soap from becoming oily. From the current analysis, the free caustic alkali for toilet soaps was found between $0.00 \%$ to $0.62 \%$ and for laundry soaps it was ranged between $0.14 \%$ to $0.99 \%$. Excess free caustic alkali causes skin itching.

\subsection{Total Fatty Matter}

Total Fatty Matter was one of the crucial characteristics describing the quality and nature of soap and it was always specified in commercial contracts. Total fatty matter values of the toilet soaps were observed from $73.37 \%$ to $100 \%$, while laundry soaps showed from $68.33 \%$ to $79.37 \%$. These differences in the TFM is responsible for high moisture contents and the kinds and quantities of the used fatty materials and also perhaps due to the difference in the saponification method. The presence of unreacted $\mathrm{NaOH}$ in the mixture shows lower TFM value [12]. However, total fatty matter above $80 \%$ is sweetable for dry skin. This makes the skin smooth, and additionally the high oil content within the soap acts as a lubricant throughout the day [13].

\section{5.pH}

For the $\mathrm{pH}$ determination, two types of solutions were analyzed. One of the solutions was prepared for $10 \%$ sample and the other was for 5\% sample. The $\mathrm{pH}$ values observed for toilet soaps were 9.69 to 9.79 , while for laundry soaps it was observed as 9.92 to 10.13 at 5\% solutions. In $10 \%$ solutions, the results were found for toilet soaps were 9.63 to 9.81 , while for laundry soaps it was observed as 10.05 to 10.32 . Incomplete hydrolysis from saponification process produces high $\mathrm{pH}$ values. The 
harshness of soap can be reduced by adding excess fat or oil or any other super fatting agent [14]. Usually, soap is alkaline to aqueous solution as it is the salt of a weak acid (fatty acid) and a base. Alkaline substances neutralize the body's protective acid mantle that acts as a barrier against bacteria and viruses. Healthy skin has a $\mathrm{pH}$ of 5.4 to 5.9 [13].

\section{Conclusion}

The results concluded that we should select a soap that keeps a balance among the physicochemical properties. Soap that contain minimum amount of moisture will increase the self life and high amounts of total fat matter helps for lubricating the skin during washing. It should also need to keep lower levels of caustic alkali to reduce harshness on skin and cloth and higher $\mathrm{pH}$ values make the soap basic and lather easily. Any soap that equipoises on these parameters in termed to be high quality soap.

\section{REFERENCES}

[1] L. Chalmers and P. Bathe, Chemical Specialist, Domestic and Industrial, 2nd ed., George Godwin, UK, 1978, pp. 1-15.

[2] Kirk-Othman, Detergency, Soap and Surfactants. Encyclopedia of Chemical Technology, Interscience, New York, 1963.

[3] Ainie K., Hamirin K. and Peang-Kean L., Chemical and physical characteristics of soap made from distilled fatty acids of palm oil and palm kernel oil, J. Am. Oil Chemists' Soc. 73 (1996) 105-108.

[4] Shoge M., Quality of soaps using different oil blends, J. Microbiol. Biotech. Res. 1 (2011) 29-34.

[5] Viorica P., Alina S. and Simona D., Quality control and evaluation of certain properties for soap made in Romania, J. Sci. Study Res. Chem. Chemical Eng. Biotech. Food Ind., 12 (2011) 257261.

[6] Roila A., Salmiah A. and Razmah G., Properties of sodium soap derived from palm- based dihydroxystearic acid, J. Oil Palm Res., 1 (2001), 33-38.

[7] Onyekwere, C., Cassava peels ash: an alternative source of alkali in soap production. BEng. Thesis, Department of Chemical Engineering, University of Port-Harcourt, Port-Harcourt, Pp: 133, (1996).

[8] Eubanks L.M., Rogers C.J., Albert E., Koob G.F., Olson A.J., Dickerson T.J. and Janda K.D., A molecular link between the active component of marijuana and alzheimer's disease pathology. Mol. Pharm., 3(6) (2006) 773-777.

[9] Kuye, A.O. and C. Okorie, Factors affecting the lixiviation of palm bunch ash as a source of alkali for soap production. Ife J. Tech., 3 (1990) 33-37.

[10] Kaoru, T., Surface Activity: Principles Phenomena and Application. Academic Press, San Diego, 1998, pp. 21-22.

[11] Ali R.J. and Geetha S., Synthesis of medicinal soap from non edible (jatropha oil) and study of its quality parameters including antimicrobial activity, Res. J. Chem. Sci., 4(4) (2014) 58-62.

[12] Roila A, Salmiah A, Razmah G, J. Oil Palm Res., 13 (2001) 33-38.

[13] Mak-Mensah E.E. and Firempong C.K., Chemical characteristics of toilet soap prepared from neem (Azadirachta indica A. Juss) seed oil., Asian J. Plant Sci. Res. 1(4) (2011) 1-7.

[14] Warra A., Wawata I., Gunu S. and Atiku F., Soap preparation from soxhlet extracted nigerian cotton seed oil. Pelagia Research Library, 2 (2011) 617-623. 